\title{
A república, o rei e a liberdade - sobre o texto “A República...” de Condorcet
}

\section{The republic, the king and freedom - about the text "The Republic..." by Condorcet}

\author{
Rodison Roberto Santos ${ }^{1}$
}

\section{Resumo}

Este artigo trata da concepção de República de Condorcet expressa no discurso: Uma República ou se um rei é necessário para a conservação da liberdade? Este discurso foi proferido na Assembleia Federal dos Amigos de Verdade e publicado pelo Círculo Social, possivelmente em 1793. Condorcet neste discurso define muito claramente o seu conceito de República, com uma configuração de poderes legislativo e executivo e cumprindo a vontade do povo. Trata-se de preservar a liberdade do povo, garantindo o regime republicano em toda sua amplitude, contrário ao regime monárquico.

Palavras chaves: República. Rei. Liberdade. Monarquia. Legislativo. Povo.

\begin{abstract}
This paper discusses Condorcet's concept of Republic expressed in the speech: A Republic or if a king is necessary for the preservation of freedom. This speech was given in the Federal Friends of the Truth Assembly and published by Social Circle, possibly in 1793. In this speech, Condorcet very clearly defines his concept of Republic, constituted of legislative and executive powers and fulfilling the will of the people. This is to preserve the freedom of the people, protecting the Republican regime in all its amplitude, contrary to the monarchy.
\end{abstract}

Keywords: Republic. King. Freedom. Monarchy. Legislative. People.

Este texto tem o propósito de mostrar como Marie Jean Antoine Nicolas de Caritat, marquês de Condorcet expôs sua defesa da República como regime político e forma de governo, e consequentemente combateu a monarquia, tanto como regime político quanto como forma de governo; ou seja, o filósofo não concordava nem com uma monarquia constitucionalista, embora teoricamente ela pudesse ser legítima, conforme a vontade do povo. Dessa forma, ele reúne num discurso, transformado depois em texto, argumentos que serviam tanto para defender a República quanto combater a monarquia. Pensamos que o movimento que o autor fez no texto comporta uma equivalência, ou seja, os argumentos que servem para combater a monarquia servem de igual forma para defender a República. Assim, ele mostra os argumentos favoráveis à monarquia e contrários à República e combate-os, invertendo as posições de defesa, o que faz com argumentos contrários à monarquia e favoráveis à República. No artigo seguimos a sequência dos argumentos que o próprio filósofo

\footnotetext{
${ }^{1}$ Doutorando em Filosofia pela Faculdade de Filosofia, Letras e Ciências Humanas da Universidade de São Paulo. Email. rodison@ usp.br
} 
organizou e procuramos mostrar seu combate e consequentemente defesa conforme a própria ordem do autor.

O problema que se apresentava no momento era como seria constituída a República e como seriam enfrentados os problemas tanto da falta de um poder forte e centralizado como o monárquico e sua substituição por um poder colegiado, no qual sua grande força residiria no poder legislativo, este partilhado por muitos, contudo eleito pelo povo. É relevante lembrar que o poder legislativo como representante legítimo do povo, com poderes efetivos de fazer as leis, promulgá-las e constituir um governo, era uma instituição nova no mundo, pelos menos para os países com vasta extensão de território, como a França. Havia um forte parlamento na Inglaterra, mas este país era uma monarquia parlamentarista. Somente os Estados Unidos da América após sua independência haviam constituído uma organização política, na qual havia a divisão de poder entre legislativo e executivo, mas todos escolhidos pelo povo. Dito de outra forma, os argumentos que se apresentavam em relação à manutenção da monarquia podiam impedir o estabelecimento de um regime político estritamente republicano, e eram esses argumentos que era necessário combater para a implantação da República. Da análise dos argumentos combativos à monarquia e favoráveis à república podemos observar quais os fundamentos que teriam essa República.

Subjacente a toda discussão no período sobre regime político e forma de governo o que era premente sustentar era uma organização, constituição e forma eficazes, para garantir a liberdade do povo. Eis o grande perigo a evitar: a perda da liberdade ou a volta a servidão. No bojo dessa garantia basilar estavam outros direitos que deveriam ser mantidos. $\mathrm{O}$ direito de fazer valer a vontade do povo em toda a organização política e mais que isto em todas as decisões sobre quaisquer assuntos referentes à nação. O direito do povo de tanto constituir representantes para as diversas funções políticas quanto à sustentação de que tais representantes fossem de fato autoridades e levassem para o centro das decisões a efetiva voz do povo. Para isto era necessário garantir a liberdade de consciência, expressão e ação dos representantes e, além disto, que este grupo assim constituído se tornasse a autoridade máxima, visto que o povo assim delegou. Salta aos olhos na leitura do texto que à luz do que faz Sièyes, no livro $O$ Terceiro Estado, Condorcet, por meio da defesa dos legisladores, está defendendo a soberania do povo, uma vez que eram os legisladores que iriam tanto codificar as leis, que o povo queria ver instituídas, quanto, por meio das autoridades, promulgá-las e executá-las. A dificuldade que o filósofo tinha de vencer era que os monarquistas também afirmavam que estavam defendendo a liberdade do povo com suas teses de que a monarquia podia ser uma forma de governo e não um regime político, e assim o rei seria uma espécie de guardião da soberania do povo. Os argumentos do filósofo se dirigem na direção desse embate.

Único filósofo iluminista a participar da Revolução Francesa, Condorcet integrava um grupo chamado Círculo Social. Eles se denominavam Amigos da Verdade e tinham, entre outras características, a de serem republicanos.

Condorcet pronunciou um discurso na Assembléia Federativa dos Amigos da Verdade que foi transformado em texto e publicado no periódico do Círculo Social com o título De la République ou Un Roi est-il nécessaire à la conservation de la liberté? Este discurso foi apresentado no período em que se definia o regime e a forma de governo do país, após a morte do rei Luís XVI. O discurso pode ser situado historicamente pelo contexto, mas não há registros da data precisa dele, que deve ter ocorrido no ano de 1793.

Embora o discurso tenha sido pronunciado na Assembléia Federativa dos Amigos da Liberdade, círculo ao qual Condorcet pertencia, seu objetivo era influenciar a Convenção Nacional, a qual também fazia parte como deputado. A Convenção 
Nacional era a instituição que, segundo o filósofo, o povo se reservou o direito de constituir para legislar em nome dele. Era nesta Convenção que estava se decidindo qual a forma de governo da França.

Se a República for entendida como um regime político no qual o povo detém a liberdade e no qual a vontade geral é representada pelo parlamento e cumprida pelo poder executivo, então a França do período revolucionário, após a queda da Bastilha, já era considerada uma República. Segundo a argumentação geral do texto observa-se que alguns realistas eram republicanos, ou seja, alguns que defendiam a monarquia no período, a defendiam como forma de governo e não mais como regime político.

Condorcet proferiu esse discurso para combater a idéia de uma forma de governo monárquica, mas subjacente a este assunto específico, o próprio discurso aponta para a idéia que o filósofo tinha de uma República, enquanto propriamente um regime político. Embora admita que, se o povo assim preferir e se ele tiver meios de manter sua liberdade, a forma de governo pode ser monárquica, o filósofo mostra em seu discurso porque ele é contrário a esta forma de governo. Sobre a decisão a respeito da forma de governo ele afirma que o legislativo "deve [...] examinar esta grande questão com toda a liberdade, toda a maturidade que merece uma decisão que pode avançar ou recuar algumas gerações." (CARITAT, 2011, p. 7).

Pensamos que as discussões que dizem respeito a uma decisão entre monarquia e república estrita, seja como regime político, seja como forma de governo, são relevantes ainda, principalmente na Europa, e o debate sobre qual é a melhor forma de governo para os Estados ainda ressurge na opinião pública, se não frequentemente sobre monarquia ou república estrita como em alguns países da Europa, porém aparecem também como modelos em outros países, como parlamentarismo e presidencialismo, por exemplo.

O discursoé organizado da seguinte forma: Depois da introdução ele apresenta alguns argumentos dos realistas e a cada um dos argumentos ele exibe seus contra argumentos; em seguida, o último dos argumentos ele subdivide em vários outros argumentos aos quais combate paulatinamente; e por último, há uma conclusão do discurso.

Logo no início do discurso Condorcet afirma: “os franceses não tem mais necessidade que a eloquência os chamem à liberdade." (CARITAT, 2011, p. 1). Esta afirmação mostra que a República francesa já estava estabelecida, uma vez que o povo gozava de sua liberdade política e por isso não era exatamente sobre o estabelecimento da República que ele iria discutir, uma vez que não eram mais necessários discursos para chamar o povo à formação da República; porém, se fazia necessário o debate sobre a constituição do governo dessa República. O filósofo justifica sua afirmação apontando os seguintes motivos da confiança em relação à firmeza do povo em manter sua própria liberdade: a coragem que os franceses demonstraram para restaurar a liberdade e a firmeza serena com a qual enfrentaram o grande perigo que os ameaçavam, que era a servidão. Para o filósofo, isso é suficiente para demonstrar que o povo será sempre fiel ao juramento de viver e de morrer pela sua própria liberdade.

Se devido à restauração da liberdade o povo instalou a República na França, o Antigo Regime sucumbira pela própria ação do povo, e um Novo Regime fora instaurado. Esta era uma das mais fortes razões para a destruição completa de uma das instituições mais fortes do Antigo Regime.

O problema que surge para a reflexão é o que diz respeito a qual forma de governo era mais apropriada para garantir a liberdade do povo, para que esta liberdade jamais esteja ameaçada, nem por usurpação de poder, nem por quaisquer artifícios dentro do próprio poder, ainda que constituído pelo povo. Os monarquistas alegavam que, ao contrário, a liberdade estaria ameaçada se a forma de governo não continuasse nas mãos da monarquia. Por isso o filósofo usa o método da inversão para mostrar que a liberdade só está assegurada na república estrita. 
Assim, é dessa forma que Caritat (2011, p. 1) explica o motivo do discurso sobre A República, afirmando que quanto ao povo "é à sua razão que é somente necessário falar dos meios de assegurar uma liberdade pacífica, afortunada e digna [...] de um povo esclarecido.” Para o filósofo, agora já consolidada a liberdade, convém pensar nas formas da sua manutenção.

Caritat (2011, p. 1) afirma quanto à monarquia que "somente a necessidade pode desculpar esta instituição corrupta e perigosa." Ele pensava que havia somente uma condição para que possa ser mantida a monarquia. E esta condição é que o povo não considerasse sua existência como essencialmente contrária aos direitos dos cidadãos. $\mathrm{Ou}$ seja, que fosse estritamente uma forma de governo, submetida ao povo e seus representantes, sem nenhuma possibilidade de usurpação do poder e como meio de manter a liberdade.

Da leitura deste texto podemos concluir que a realeza é então vista como perigosa para a liberdade política, porque em um regime onde o povo está submetido aos caprichos de um homem, nele o povo fica subjugado aos interesses de uma família - a família real -, de uma classe - a nobreza - e da igreja, ou mais precisamente do clero. Para Condorcet, todos estes domínios ensejavam uma servidão, da qual os homens deveriam se libertar. Isto nos mostra que livrar-se da monarquia, até mesmo como forma de governo, era livrar-se do despotismo e da servidão destes domínios.

Os argumentos dos realistas são então apresentados e refutados da seguinte maneira:

O primeiro argumento: "é necessário um rei para não haver um tirano: um poder estabelecido e limitado pela lei é bem menos redutível (à usurpação) que o poder usurpado por um chefe que não tem outros limites que aqueles de seu interesse e de sua audácia." (CARITAT, 2011, p. 2).

Condorcet afirma contra isso que a França não precisa ter medo dessa espécie de usurpador. Isso porque a divisão do poder em departamentos resulta por tornar impossível esse projeto ambicioso de usurpação. Assim contra um poder concentrado nas mãos de uma pessoa, há o poder dividido por instituições, o que impede muito mais a usurpação.

$\mathrm{O}$ pacto federativo impediria também que o ídolo da capital se tornasse um tirano dentro do país e tal ocorreria porque a extensão do país é mais favorável ao regime republicano. Outro impedimento a esta usurpação é uma divisão do poder fundada não somente na lei, mas também nas divisões reais das funções públicas. Estas divisões são mais uma barreira à usurpação do poder na República federativa. Ex. o exército, a marinha, a administração das finanças, a justiça, por exemplo, são cargos ocupados por homens que tem educação, luzes e hábitos essencialmente diferentes. Para que alguém aspirasse à tirania numa República seria necessário destruir, corromper e modificar todos esses poderes.

Com todas estas medidas preventivas Condorcet pensava que estaria assegurado que o poder não fosse usurpado por corporações ou grupos que tomassem o poder de forma violenta ou por meio de artifícios e, assim, estariam a salvo de tiranos; ou seja, daqueles que a todos submetem à sua vontade, ou de grupos, que de uma forma ou de outra, conduzem o poder.

Embora se cercando de muitas medidas que considerava tanto eficientes como suficientes, para impedir a usurpação do poder, o filósofo não consegue ver o problema que ocorreria se todo o aparato governamental se tornasse corrompido. Pois ao dividir as funções públicas para que sejam exercidas em nome da república e as quais ficam repartidas em muitas mãos, sem a obediência a um homem que representa o poder central, como o monarca, ele não considera o perigo deste corpo que na sua grande parte tornar-se corrompido. Ele não considera a possibilidade de em cada uma das funções do governo os homens ao invés de trabalharem pelo bem público, trabalharem cada um tão somente para seus próprios interesses.

Pensamos que Condorcet deixa de ponderar 
sobre a possibilidade de uma corrupção geral na república porque tem diante de si uma das medidas que, conforme seu pensamento, é uma das mais poderosas para impedir esta doença do corpo político. Esta medida é a instrução pública.

Podemos apreender de seus escritos sobre a instrução pública esta medida a mais impeditiva para a corrupção na república, pois com a educação os homens se tornariam de fato republicanos. Assim, na visão do filósofo, não haveria nem o perigo das instituições se corromperem ou este perigo seria tão diminuto que não deveria nem ser considerado. Esta instrução serviria também para construir a defesa e o respeito da república por parte dos cidadãos. E conforme ele, para ampliar os efeitos da instrução, as medidas externas ao próprio poder que serviriam de barreiras para a usurpação dele seriam a liberdade de imprensa, o uso quase universal da leitura e a multidão dos documentos públicos abertos ao povo. Estas medidas são, segundo Condorcet, suficientes para prevenir o perigo da usurpação do poder por um tirano.

O filósofo busca na história da Inglaterra um exemplo para a necessidade de difusão da leitura. Ele afirma que uma das coisas pela qual Oliver Cromwell se tornou tirano foi que o povo da Inglaterra lia somente a Bíblia e por isso é necessário a propagação da leitura sem uma interferência religiosa; ou seja, é necessária a difusão de livros que não tenham somente objetivo de doutrinação, mas também de livros que levem as pessoas a pensar de maneira autônoma.

Como já vimos anteriormente, um dos inimigos da república é a condução religiosa do clero na política, ou seja, a influência do clero nas decisões referentes a tudo aquilo que interessa ao seu domínio com seu arsenal de moralidade, superstição e perseguição a toda liberdade, e no que diz respeito também à liberdade de expressão escrita. Isto gera obscurantismo e difusão de mais ignorância, acarretando controle de todas as obras que o povo deveria ler.
Outro aspecto importante para o combate à tirania é a transparência em relação ao poder. Quanto a isso o filósofo afirma: “os tiranos populares só podem agir sob a máscara e desde que exista um meio de forçálos a agir com a face descoberta, eles não podem mais oferecer perigo.” (CARITAT, 2011, p. 3).

Condorcet era leitor de Rousseau, nesta afirmação podemos ouvir o eco dos escritos de Rousseau, quando mostra o homem que põe diante de si a máscara do poder para dominar o povo e assim tornar-se um tirano. No entanto, se a ninguém for permitido agir sob máscara, impedese que ocorram a emergência de tiranos, pelo fato de eles não poderem mais enganar o povo. É assim a transparência do homem em relação a si mesmo que se transforma em uma poderosa arma contra a tirania, consequentemente contra a monarquia. Ocorre aqui, então, a dupla proteção aos perigos, tanto da república nascente, quanto contra a volta da monarquia. Na república porque não poderia mais surgir tiranos nela e contra a monarquia porque o povo não mais aceitaria nem o antigo, nem constituiria um novo rei.

No final da sua contra argumentação Condorcet mostra sua convicção de que a França estava livre da tirania. Ele afirmou que não se deve procurar fazer um mal real - o restabelecimento da monarquia -, para prevenir um perigo imaginário - a usurpação do poder de um tirano.

Ao segundo argumento: “Um rei é necessário para preservar o povo da tirania dos homens poderosos" (CARITAT, 2011, p. 3). a resposta é que a constituição não permite mais que haja homens tão poderosos que possam usurpar o poder. Isto porque não há mais dignitários, prerrogativas hereditárias e a divisão igualitária das sucessões, a publicidade de todas as operações financeiras, a administração popular do imposto, e a liberdade do comércio limitaram suficientemente a desigualdade de riqueza.

Ao destruir a nobreza, o poder do clero e os corpos perpétuos de magistratura, o povo francês destruiu tudo o que tornava útil à proteção de uma 
monarquia. Fizeram a reforma dos abusos do poder e assim inutilizaram a própria monarquia, e por isso não há abertura para emergir tiranos.

Vemos que pensar em manter ou constituir um homem para preservar o povo dos abusos de poder dos homens poderosos implica em um pensamento de subjugação, ou seja, constitui-se alguém para proteger o povo de outros. É um argumento insustentável quando se reflete sobre liberdade e principalmente sobre a igualdade. É referendar a desigualdade como pertencente de forma quase natural à sociedade humana. E no pensamento de Condorcet a igualdade deve ser parte integrante da sociedade, e se não puder ser instituída na sua inteireza, pelas dificuldades inerentes à própria sociedade, pelo menos deve ser garantida como direito e como horizonte constante de busca de condições para efetivá-la.

O combate ao terceiro argumento é também a terceira divisão do texto. É muito importante porque é uma indagação que põe em dúvida a própria credibilidade do poder legislativo. $\mathrm{O}$ argumento dos realistas era que um rei era necessário para defender os cidadãos das usurpações de um poder legislativo.

Este terceiro argumento é crucial para Condorcet atacar porque ele é o que confronta diretamente o poder legislativo. Podemos nos lembrar que todo o objetivo do texto é defender a liberdade na República. Dessa forma, afirmar que o poder legislativo pode suprimir a liberdade do povo é desmontar todo o alicerce da república representativa. Isto porque a instituição que foi constituída para fazer com que a vontade do povo fosse realizada, seja por meio de leis, seja por meio de medidas, seria a usurpadora de um poder que lhe foi outorgado.

Não podemos deixar de admitir que este receio dos realistas não era infundado, a história subsequente mostrou que, por muitos deslizes e por muitos interesses alheios à vontade do próprio povo, o poder legislativo, seja por má fé, ignorância, por acordos espúrios ou quaisquer outros motivos, passou muitas vezes ao largo da vontade do povo e zombou algumas vezes da soberania popular. A solução de Condorcet comporta problemas, mas não podemos esquecer que era uma instituição nova que se constituía sobre a terra e que realmente era difícil prever alguns problemas, mas mesmo os apontados estavam sendo alvo de ponderações sobre as soluções por meio deles; soluções por vezes insuficientes, mas pensadas como formas de dirimir as dificuldades.

Aqui ocorre um problema da teoria de Condorcet em relação à teoria de Rousseau. Para este o legislador não deveria ser investido de poder sobre o povo, porque o legislador é somente um guia, um tradutor da vontade geral em leis as quais o povo aprovará e seguirá. No entanto, cumprido o objetivo de fazer estas leis, inscritas no coração do povo, transformando-as em um código escrito e claro para ele, o legislador não pode mais exercer autoridade sobre o povo. Além disso, Rousseau não admite representação entre o povo, uma vez que para ele ninguém deve representar o povo na sua vontade geral. No entanto, no período da Revolução Francesa, os representantes do povo se tornaram a única forma de fazer com que a voz do povo fosse ouvida e contemplada nos Estados Gerais, depois na Assembleia Nacional e em seguida na Convenção Nacional. Dessa forma, mesmo tendo o Contrato Social como gramática da Revolução, os republicanos estritos entenderam que somente conferindo uma autoridade aos representantes poderiam destruir o poder despótico do rei. Mesmo passando além do papel do legislador em Rousseau e conferindo-lhe autoridade, os revolucionários mantiveram a provisoriedade dos representantes, promovendo também uma espécie de intercurso, pelo menos por carta, no qual os representantes ouviriam a voz do povo para fazer leis que contemplassem sua vontade.

A resposta de Condorcet é que o receio dos monarquistas não se justifica porque não se trata de um poder legislativo que era ligado anteriormente à monarquia. Além disso, trata-se de um poder frequentemente renovado, ou seja, não é permanente. 
A forma de escolha também impede a usurpação, pois os representantes são escolhidos entre os cidadãos e os oficiais públicos. Os executores das leis são escolhidos também pelo povo e as leis que regem suas ações eles não têm o poder de mudar. Outra barreira à usurpação pelo poder legislativo é o direito de o povo convocar convenções nacionais em datas fixas.

Em se tratando do legislativo em vigor na época, a constituinte ainda estava se formando e por isso poderiam ser estabelecidas leis que impedissem a usurpação, visto que segundo ele "não se quer criar o mal para ter necessidade do remédio" (CARITAT, 2011, p. 4).

Como vemos a liberdade não era assim tão facilmente assegurada nem na república. Contudo, podemos dizer que se ela era ameaçada na própria república, na monarquia ela era impedida de ocorrer, porque para o filósofo a monarquia, mesmo como forma de governo é essencialmente inimiga da liberdade. Mesmo tomando o poder legislativo como defensor da liberdade do povo, as ameaças sempre existem em relação à usurpação. No entanto, a república é o regime por excelência da liberdade, e o que transparece é que Condorcet, mostrando as formas de proteger a liberdade da república, quer demonstrar que o povo em cada perigo que apareça para ameaçar sua liberdade vai saber defenderse e mantê-la. E esta força do povo só ocorre na república.

Ao argumento seguinte dos realistas que um rei é necessário para que se previna da tirania do próprio poder executivo, pois é melhor ter um senhor que muitos, Condorcet contra argumenta que não seria necessário nenhum tipo de senhor, pois um conselho executor das leis não pode aspirar a ser senhor se os limites das suas funções são bem fixados, se são eleitos pelo povo, se não gozam de uma importância individual, e são fiscalizados pelo poder legislativo.

Assim, um pequeno número de homens investidos por um momento de um poder limitado não poderia formar um projeto para estender os limites desse poder até torná-lo um poder pessoal. Só se poderia temer em relação a eles somente opressões particulares às quais seria necessário opor não um rei, mas leis e juízes.

Quanto ao argumento dos realistas que um rei é necessário para dar força ao poder executivo, o contra argumento de Condorcet é que a única força real em um país livre é a força da nação, e assim os poderes estabelecidos por ela e para ela só podem ter a força que nasce da confiança do povo e de seu respeito pela lei. Complementa que quando a igualdade reina, é necessária muito pouca força para obrigar os indivíduos à obediência e ao interesse de todas as partes do poder para que nenhuma delas se furte à execução das leis que os outros reconheceram.

Condorcet critica o costume de tratar os assuntos públicos como se ainda estivessem no tempo em que as associações poderosas davam a seus membros o odioso privilégio de violar as leis. Somente neste caso seria necessário que se desse aos chefes do poder executivo uma grande força.

Ele admite que, quando fora instituída a monarquia, existia abuso e perigo contra os quais a existência de um rei foi útil. Sendo assim, as instituições humanas as mais viciosas são somente remédio destinados a males reais e não imaginários. Se os homens não fazem a si mesmos mal somente pelo prazer de sofrer, então a submissão sempre voluntária na origem só ocorria por motivo de uma utilidade presente bem ou mal estendida.

É ao contrário a existência de um chefe hereditário que tira do poder executivo toda sua força útil, armando contra ele a desconfiança dos amigos da liberdade, obrigando-o a proporcionar-lhe entraves que embaraçam e retardam seus movimentos. A força que a existência de um rei daria ao poder executivo seria somente vergonhosa e nula, essa força só poderia ser aquela da corrupção.

Nesta série de argumentos contra a garantia de que um rei protegeria o povo da usurpação do poder executivo, Condorcet além de salvaguardar 
a liberdade, defende de igual maneira a igualdade. Por esta dupla defesa que é mostrada claramente aqui, concluímos que para que a liberdade seja defendida numa república é necessário defender na mesma medida a igualdade. Podemos afirmar que os homens só são livres se forem iguais em direitos, deveres e condições. Ora, a monarquia é o regime político e a forma de governo estabelecida sob a desigualdade. É somente na república que a igualdade pode se manifestar em toda sua extensão e força. O poder executivo na república é somente o executor das leis, as quais o povo aprovou; estas feitas por representantes eleitos por ele para codificar na escrita o que perpassa na vontade do povo. Neste sentido, nenhuma forma de arbítrio poderia ser aceita ou cometida pelo poder executivo na república, o que seria mais difícil de combater na monarquia.

Condorcet sabe dos perigos do poder executivo, mesmo na república, já fora avisado por Rousseau no Contrato Social ${ }^{2}$ que todo governo é perigoso para o corpo político. Contudo, para ele é mais adequado prevenir o poder executivo na república de uma usurpação, criando leis e mecanismos para tais e da mesma forma criar limites para o seu poder. Quanto à monarquia, tanto pelo costume quanto pela história, seria muito mais temeroso mantê-la, mesmo que o limitasse; mesmo assim, o povo correria mais risco em relação à sua liberdade, além de referendar a desigualdade, pois o fato de haver uma pessoa que de alguma forma estaria acima das outras pessoas, já se tornava funesto para as considerações sobre a igualdade.

Foi para mostrar o erro da desigualdade política que, para combater a teoria do direito divino da monarquia, Condorcet argumentava que já havia passado o tempo em que os homens consideravam o rei como investido de poder divino para governar, porque seus súditos acreditavam em superstições.
Ele afirmou que "sem dúvida não cremos mais que é necessário para governar os homens manipular suas imaginações por um luxo pueril e que o povo será tentado a desprezar as leis de seu supremo executor não tendo um grande senhor [...]" (CARITAT, 2011, p. 5-6).

Podemos ver que o embate de Condorcet com a religião não ocorre somente em relação ao poder do clero, mas também contra o poder de crenças infundidas por ele. Vemos então assim que o filósofo destrói a crença, que advém da antiguidade, que o poder do rei é um poder divino. Esta crença é supersticiosa, e um artifício para a manutenção da desigualdade e, consequentemente, torna-se funesta para a liberdade. Ao lermos sobre a história da religião e da política, observamos que a religião teve o papel de alimentar nos costumes de pensamento sobre a política esta confusão entre o direito divino - religioso - e o direito político - temporal - dos reis. A força deste preconceito entre o povo conferia ao rei um poder imaginário que entranhava um despotismo da arbitrariedade, pois se Deus dava ao rei o poder temporal, o rei investido do poder, destruindo toda igualdade, poderia dispor da vida dos súditos, destruindo a liberdade. Foi por isso que usando um termo advindo de Espinosa - imaginação -, Condorcet combate a manipulação da imaginação que leva ao misticismo e se imiscui na política para dar legitimidade religiosa e política à monarquia.

Condorcet combate a remissão à história das sedições das repúblicas antigas para justificar a monarquia. Segundo ele, remeter-se à história dessa forma demonstra conhecimento de acontecimentos da história, mas não um profundo conhecimento da história. Aqueles que se assustavam com tumultos, injustiças, corrupção de algumas repúblicas antigas, não sabem analisar as razões dos problemas, as diferenças das repúblicas antigas para o novo modelo de república e as soluções prévias para os

\footnotetext{
2 O clube Os Amigos da Verdade, do qual Condorcet fazia parte lia e interpretava o Contrato Social como uma espécie de guia para a Revolução.
} 
possíveis problemas da república. Somente quando se examina estas repúblicas é que se observa que há nelas em geral um povo soberano e também povos dependentes, submissos a ele, e por isso, desde sempre há grandes meios de corromper o povo soberano e um grande interesse em seduzilo. No entanto, nem este interesse, nem estes meios existem quando a igualdade é completa entre todos os habitantes do império. O império de uma multidão sobre outra multidão é o mais odioso dos tiranos, seja quando o povo de uma cidade reine sobre um grande território, quando aquele de uma província domine pela força uma província vizinha, ou que enfim nobres espalhados pelo país sejam os senhores daqueles que lá habitam; estas formas de corpo político são as mais perigosas para o povo tanto para os que obedecem quanto para os que comandam. Mas é contra tais formas que combatem os verdadeiros amigos da liberdade, aqueles que querem que a razão e o direito sejam os únicos senhores dos homens.

Condorcet dizia que a França não estava mais sujeita à avidez de chefes. Afirmava que um general francês não poderia mais despojar províncias conquistadas para comprar os sufrágios dos franceses. Não haveria mais a possibilidade de um ambicioso propor aos franceses, como foi feito aos atenienses, pagar os tributos aos aliados para a construção de templos ou a promoção de festas; e prometer aos soldados franceses a pilhagem de territórios, como foi feito aos cidadãos de Roma com a pilhagem da Espanha ou da Síria. Assim, era porque os franceses continuariam sendo um povo livre que eles não podiam mais ter um rei. Dessa forma, de todas as razões que são alegadas em favor de um poder hereditário, nenhuma delas era aplicável à nação francesa a partir daquela época.

Havia mais argumentos em favor da monarquia, como, por exemplo, a unidade da atividade do poder executivo, que era um privilégio exclusivo da monarquia; a necessidade de conservar mais tempo a instituição mais própria à corrupção quando os costumes se corrompem e a impossibilidade de constituir uma grande república, o interesse particular da capital em conservar um rei e prover um pagamento a ele. Contra esses argumentos Condorcet afirmava que não era correta a oposição que se procurava fazer surgir entre a capital e as províncias, como se a liberdade e a igualdade não fossem atualmente os primeiros dos desejos e das necessidades dos franceses; também não era apropriada a censura ao fato de querer uma república, após ter jurado manter a constituição monárquica; e que é uma máxima da tirania e da inquisição o fato de dar a um juramento a força para comprometer tanto os pensamentos quanto as ações. Na república havia a vantagem em que o governo não só executa as leis, mas as têm como boas e o povo não só as obedece, mas também acredita nelas.

Disso tudo se pode dizer que não era suficiente e eficiente utilizar nem a história, nem artifícios de guerra, nem simplicidade de poder, nem costumes. Todos os argumentos foram refutados por Condorcet um a um. O que é mais importante ressaltar é que a liberdade é incompatível com a monarquia. Se é a liberdade que é necessária preservar, e se ela só é inaugurada com a igualdade, logo essa seria contrária à monarquia, lugar por excelência da desigualdade. Então a liberdade só se dá na república. Só a república é o regime da liberdade, indispensável ao povo e aos seus representantes.

Em defesa da Convenção Nacional, Condorcet afirmou que não se podia tratar como loucos aqueles que tinham a felicidade de pensar como os sábios de todos os tempos e de todas as nações. É àqueles que, naquele momento, a nação francesa confiara o direito de lhe propor uma constituição que pertencia o direito de determinar qual forma, após um acontecimento que livra o povo de seus compromissos com o monarca, que convinha formar um poder executivo. Eles tinham perante os cidadãos o dever de examinar esta grande questão com toda liberdade, toda a maturidade que merecia uma decisão que podia avançar ou recuar por algumas gerações, os progressos do espírito humano. 
Condorcet afirmava também que até aquele momento eles não haviam decidido sobre a forma de governo, por isso eles se reservaram o direito de nomear um preceptor para o delfim, eles não se pronunciaram se o delfim devia reinar; mas somente afirmaram que seria possível que a constituição o destinasse para tal; eles quiseram que a educação, destruindo tudo que o prestígio do trono pode inspirá-lo como preconceitos sobre os direitos pretendidos de seu nascimento, que esta educação lhe fizesse conhecer no melhor momento, a igualdade natural dos homens, a soberania do povo; que ela the ensinasse não mais esquecer que o povo terá o título do rei e que o povo não tem o direito de renunciar o poder de destituí-lo. Eles quiseram que esta educação o tornasse igualmente digno, por suas luzes e suas virtudes, de receber com resignação o fardo perigoso de uma coroa, ou de depor com satisfação nas mãos de seus irmãos, que ele sentisse que o dever e a glória de um rei de um povo livre é o de reconhecer o momento de não ser mais que um cidadão ordinário. Eles quiseram que a inutilidade de um rei, a necessidade de procurar os meios de substituir um poder fundado sobre ilusões, fosse uma das primeiras verdades oferecidas à razão do delfim. Eles não ignoram que neste momento o que se tratava era bem menos de formar um rei, mas muito mais de lhe ensinar a ponto de ele não querer mais ser um rei.

Condorcet conclui afirmando que os homens que quebraram os grilhões da feudalidade e da superstição, que enfraqueceram a tirania judiciária e financeira; os redatores da primeira declaração dos direitos do homem e dos cidadãos, dos quais a Europa podia se orgulhar, seriam fiéis à sua glória. Eles não renovariam livremente aquelas leis infelizes, aquelas honras exageradas que o medo dos pretores impôs ao senado dos imperadores; se eles se mantinham em silêncio ainda, era porque refletiam sobre estes grandes assuntos não como árbitros, mas como os intérpretes da vontade nacional; eles esperavam que ela fosse claramente manifesta para obedecê-la.

Citaremos um trecho do livro L'idée républicaine en France (1789-1924); essai d'histoire critique ${ }^{3}$ de Claude Nicolet, para esclarecer que o debate sobre o republicanismo na França era uma novidade. Com isto, estavam fundando uma nova organização política, e a liberdade nesta nova organização é quase sinônima da república. $\mathrm{O}$ fato novo é que surgia uma república moderna, ou seja, não eram mais repúblicas de estados pequenos, os quais são regidos ou por aristocracias ou por democracias diretas; surgiam repúblicas representativas, com estados com grandes extensões, onde os representantes eleitos pelo povo acorriam para a capital para decidir sobre assuntos referentes a todos e constituir o governo. Eis a citação:

\begin{abstract}
Pretende-se sempre que antes da Revolução não há o menor traço na França de uma teoria ou de uma doutrina republicanas: a França toda era monarquista, da nobreza ao terceiro estado, sustentáculo do absolutismo e dos privilegiados que, denunciando os "abusos", queriam reformas dos desejos no quadro da monarquia e o mais certo, sob a Regência ou sob o reino de Luís XVI, ousariam sonhar com uma mudança da pessoa do rei ou da dinastia. É um fato que os Cadernos de queixas (Cahiers de doléances) mostram a importância e a persistência do que se pode chamar a "mística" real nas massas. Entretanto, o problema da forma republicana do governo dos Estados, de suas condições e de seus limites, tinham sido frequentemente postos, ao menos desde a Renascença e em termos que não eram estritamente acadêmicos (NICOLET, 1982, p. 23-25).
\end{abstract}

Da exposição destes argumentos do discurso podemos concluir que Condorcet estava lançando ali os fundamentos da República moderna. Quais são então estes fundamentos? Sem enumerá-los para não dar-lhes um grau hierárquico podemos dizer que a república moderna é em princípio um regime regido pela vontade do povo. Ela sustenta um poder legislativo forte, sendo assim um regime representativo. Esse legislativo tem a incumbência

\footnotetext{
${ }^{3}$ A Ideia Republicana na França (1789-1924) Ensaio de história crítica.
} 
de organizar esta República, elaborando as leis e organizando os sistemas de poder.

Dessa forma a liberdade é constitutiva da República. Por isso, para Condorcet a forma de governo era uma deliberação do legislativo, mas depois de consultada a vontade do povo e mesmo que fosse a monarquia - se o povo assim o desejasse, só poderia ser uma monarquia constitucionalista, uma vez que o povo não poderia jamais transferir seu poder a um monarca.

O filósofo, contudo, aponta os inconvenientes da monarquia. Diferente da monarquia na qual o povo empresta sua confiança ao monarca para exercer o poder executivo, ficando assim o poder na mão de uma só pessoa, o poder deve ser dividido e compartilhado por muitos, para evitar o perigo de usurpadores e a ascensão de tiranos. Disso podemos concluir que quando o poder encontra-se partilhado por muitos pode haver um controle maior das ações para que ninguém possa usurpá-lo dificultando assim a emergência da tirania.

Um dos instrumentos para a manutenção da liberdade e da igualdade é a liberdade de imprensa, por isso deveria haver liberdade de expressão e de imprensa e divulgação do conhecimento. Somente quando todos partilhassem de um certo nível de conhecimento que ensejasse uma igualdade é que se poderia assegurar uma liberdade, pois o esclarecimento é essencial para a república e seus cidadãos.

Se a república é o regime da igualdade, então para Condorcet deveria haver medidas para a diminuição das desigualdades, como a extinção de privilégios nobiliárquicos, hereditários, e religiosos, e tal mudança ensejava a participação de todos nos negócios públicos.

Diferentemente do poder monárquico que era vitalício e hereditário, o poder legislativo, único poder legítimo, pois advém diretamente do povo, deve ser temporário e ser eleito periodicamente. Isto implica em compromisso de os representantes obedecerem à vontade do povo e só cumprirem aquilo para o qual eles estão estritamente delegados.

Por fim, Condorcet proclama a laicidade da República, pois não deve haver proeminência de nenhuma religião e nenhuma instituição deve ter símbolos religiosos. Tal relação com a religião não implica que o Estado aja contra a religião, mas, ao contrário, garantir a laicidade é garantir o direito de todas as religiões, como a religião dos judeus e dos protestantes, por exemplo. Na medida em que nem o Estado, nem os poderes dele estão submetidos a uma só religião, ele garante liberdade de consciência a todos os homens para seguirem a religião que desejarem.

Pensamos que com estes argumentos Condorcet estabelece as bases da liberdade na república contemporânea. Eles não são de somenos importância porque ainda nos dias atuais estas questões são discutidas, tais como liberdade, igualdade, laicidade, relação de regulação e independência entre os poderes, seja legislativo, executivo ou judiciário. A importância da garantia da liberdade e da igualdade goza atualmente de consenso; contudo, o que se discute, de forma mais específica, são as maneiras sub-reptícias pelas quais podem ser ou são solapados estes alicerces da república moderna e como prevenir a emergência dos erros e dos abusos contra o próprio sentido de república, que é o governo que contempla a vontade do povo. Dessa forma, vez por outra seria necessário voltar a um ou outro argumento para defender a república, em toda sua complexidade e extensão.

\section{Referências}

BADINTER, E.; BADINTER, R. Condorcet: un intellectuel en politique. Paris: Librairie Arthème Fayard, 1988.

BAKER, K. M. Condorcet: from natural philosophy to social mathematics. Chicago, London: The University of Chicago Press, 1975.

BUISSON, F. Condorcet. Paris: Librairie Félix Alcan, 1929. 
CARITAT, J. A.N. (Marquis de Condorcet). De la république ou un roi est-il nécessaire à la conservation de la liberté? Discours dont l'Assemblée Fédérative des Amis de la Vérité a demandé l'impression, en votant des remercîmens à son Auteur. Disponível em: $<$ http//gallica. bnf.fr>. Acesso em: 20 abr. 2011. Como devo abreviar?

Cinq memoires sur l'instruction publique. Paris:

Flammarion. 1994.

Esboço de um quadro histórico dos progressos do espírito humano. Tradução Carlos Alberto Ribeiro de Moura. Campinas: UNICAMP. 1993.

. Esquisse d'un tableau historique des progress de l'esprit humain.Paris: Edition, 1966.

. Sur Les Élections et autres Textes. Paris: Librairie Arthème Fayard,. 1986.

COUTEL, C. (Org.). Politique de Condorcet. Paris: Payot \& Rivages, 1996.

ESPINOSA, B. Tratado teológico-politico. Tradução de Diogo Pires Aurélio. São Paulo: Martins Fontes. 2008.

FERNANDES, F. Resenha da obra: Granger, GillesGaston. La Mathématique Sociale du Marquis de Condorcet. Paris: Presses Universitaires de France, 1956. O Estado de São Paulo, São Paulo, 11 maio 1957. Suplemento Literário p. 2.

GRANGER, G.-G. La mathematique sociale du marquis de condorcet. Paris: Odile Jacob,1989.

NICOLET, C. L'idée republicaine en france (1789-1924) essai d'histoire critique. Paris: Gallimard, 1982.

ROUSSEAU, J.-J. $O$ contrato social. Tradução de Lourdes Santos Machado. São Paulo: Abril, 1973. Coleção Os Pensadores.

SCHANDELER, J.-P. Condorcet et l'invention de la perfectiblite indefinie: une contribution aux «sciences morales et politiques» l'homme perfectible. Paris: Champ Vallon, 2004.

. Condorcet et l'histoire de la raison: la formation de l'idee de conflit. In: BINOCHE, B.; TINLAND, F.; BOURDIN, J.-C. Sens du Devenir et Pensée de L'Histoire au Temps des Lumières. Paris: Champ Vallon. 2000. p. 209-226.

SIÈYES, E. J. Qu'est-ce que le tiers-état?. Disponível em: < disponível no site http/gallica.bnf.fr >. Acesso em: 20 abr. 2011. 